\title{
GCU
}

Glasgow Caledonian

University

University for the Common Good

\section{Entrepreneurship education in Brazil: Brazilian and Scottish approaches to policy and provision in vocational education}

Stadler, Adriano; Alberton, Anete; Smith, Anne

Published in:

Journal of Small Business and Enterprise Development

DOI:

10.1108/JSBED-12-2020-0440

Publication date:

2022

Document Version

Author accepted manuscript

Link to publication in ResearchOnline

Citation for published version (Harvard):

Stadler, A, Alberton, A \& Smith, A 2022, 'Entrepreneurship education in Brazil: Brazilian and Scottish approaches to policy and provision in vocational education', Journal of Small Business and Enterprise Development, vol. 29, no. 4, pp. 645-662. https://doi.org/10.1108/JSBED-12-2020-0440

\section{General rights}

Copyright and moral rights for the publications made accessible in the public portal are retained by the authors and/or other copyright owners and it is a condition of accessing publications that users recognise and abide by the legal requirements associated with these rights.

Take down policy

If you believe that this document breaches copyright please view our takedown policy at https://edshare.gcu.ac.uk/id/eprint/5179 for details of how to contact us. 
Entrepreneurship Education in Brazil: Brazilian and Scottish Approaches to Policy and Provision in Vocational Education

\begin{abstract}
Purpose: Our paper examines entrepreneurship education (EE) in Brazil and Scotland and unpacks convergent and divergent practices in Vocational Education (VE). We evaluate access to Entrepreneurship Education in VE and suggest and how it might be advanced in Brazil.
\end{abstract}

Design/ methodology/ approach: The authors conducted an Interpretative Phenomenological Analysis (IPA); interpretative analysis of interviewee experiences with twelve educationalists, in management and academic roles, from two Brazilian and two Scottish VE institutions, contextual findings inform advances.

The findings of this study: In Scotland, there is a well-defined entrepreneurial ecosystem where government policy and partners support and monitor provision of and accessibility to EE. In Brazil, government does not regulate policy provision of EE and there is no defined entrepreneurial ecosystem of partners. IPA enabled the authors to examine divergent entrepreneurial education provision and evaluate accessibility to EE in Brazil.

Research limitations/implications: Implications include ways to advance educational inclusivity and accessibility for VE students in Brazil and a call to address availability through policy is underpinned by empirical data. Contextual characteristics of the study might be considered limiting but address a broad call to contribute to EE in VE settings.

Practical implications: The findings of this study equip educationalists with new knowledge about advancing EE provision and delivery in VE, which in turn supports inclusivity.

Originality/value: We contribute directly to an agenda that will create impact for young Brazilians through accessible entrepreneurship education models, that place entrepreneurship education in VE at the forefront of social change in Brazil.

Key words: Entrepreneurial education; Vocational education; Accessibility; Employability; Work-ready graduates; Interpretative Phenomenological Analysis.

Type: Research Paper

\title{
Introduction
}

From Primary to Professional Learning Communities (PLC's), Enterprise and Entrepreneurship Education (EEE) appears fruitful as a focus of study by researchers. Notably, different levels of education receive different levels of attention from researchers and policy makers, and Vocational Education (VE) is known to attract less attention than others (Liguori et al., 2019). The guest editorial in JSBED, Liguori et al., (2019), invites scholars to broaden their thinking and consider further context based educational seams that exist beyond the traditional domains of EE programs in Higher Education. Liguori et al., (2019) describe VE as a void in our EE 
knowledge, a neglected population yet one that includes vast numbers of students who create business and enter the workplace not fully prepared with enterprise or entrepreneurship skills or mind-sets. Vocational Education (VE) contributes to national economies and encourages students to apply enterprise skills in the labour market, whether as employees or new businesses owners (Brunetti and Corsini, 2019), and as an under researched domain of EE, VE is without doubt a fruitful area of EE research.

Accessibility to EE in VE has never been more relevant, according to the British Council (2017, s.p.), 'growing youth populations, coupled with rising youth unemployment in many countries, is putting greater emphasis on job creation and enterprising behaviour within employment.' Moreover, access to innovation and entrepreneurship programs are influencing workplaces and changing how businesses operate and contribute to economic development (Medeiros et al., 2020). As a result, it is possible to observe an ever-increasing interest from government and educational authorities from across the world to find ways of embedding and creating access to EE in VE. Equipping students with EE skills and mind-sets from all educational backgrounds and encouraging career aspirations, is fundamental in what is now a complex and dynamic labour market.

Brazil is no exception among the nations that acknowledge the key role of $\mathrm{EE}$ in VE as a way of increasing the employment prospects of its youth population. Yet despite the socio-economic challenges facing Brazilians students there is a high demand for entrepreneurship education at different levels of educational institution. Lima et al., (2015), conduced a study to identifies challenges and opportunities for enhancing higher education in entrepreneurship; in Brazil, the results shows us that aroud $50 \%$ of students declared an entrepreneurial intention and demonstrates a demand for entrepreneurship education at universities and colleges. Such positive attitudes towards entrepreneurial destinations, these Brazilian students suggest there is an overwhelming appetite for more than just business planning courses. Lima et al., (2015) call for contextualised studies and deeper examination of the Brazilian entrepreneur. Social initiatives like SEBRAE (Brazilian Micro-Enterprise and Small Business Support Service - a quasi-government agency similar to the American Small Business Administration) offer Brazilians, a wide range of free-online courses on entrepreneurship. However, in relation to formal education, there remains that notable gap in accessibility of entrepreneurship training at all levels, especially in primary, secondary and in vocational education (Liguori et al., 2019; Torun and Tumen, 2019; Aamir, Atsan and Erdem, 2019). Data reveals that less than 10\% of 
Brazilian adults from 18 to 64 years old have had any entrepreneurship training (Zacharis, 2013). Moreover, according to Kuenzer (2006), the model of EE in VE being practiced in Brazil since the 1980's, is not efficient in terms of placing students at high level positions in corporations. To this, Oliveira (2015) adds that inefficient or inexistent educational policies are directly linked to the low standard of public education in Brazil, resulting in the formation of a workforce only capable of adapting subjectively and technically to precarious jobs. Deitos and Lara (2016) affirm that the argument of formative deficiencies in the workforce, present in VE policies, is not being properly addressed, since only $20 \%$ of positions require higher levels of qualification in the productive sectors.

Scotland, on the other hand, has established the objective of being a 'world-leading entrepreneurial and innovative nation'. To pursue this goal, the Scottish government implemented policy enabling a model where universities have a central role to play in EE, along with 'public and private business support agencies, industry and a range of other actors' (The Royal Society of Edinburgh, 2015). Sponsored by the Scottish Government, Scotland is attempting to shape and drive forward an effective and highly accessible entrepreneurial ecosystem supporting nascent entrepreneurs from an array of backgrounds with many levels of education (Scotland Can Do, 2021). The Can Do Initiative is shaped by government policy and regional partners, a co-ordinated effort of diverse support with a common goal of accessibility and inclusivity; according to Jung et al., (2017) regional efforts supported by government are an essential feature and characteristic of entrepreneurial ecosystems.

Nonetheless, Brazil and Scotland, two very different contexts; Welter's (2011) framework highlights how Brazil and Scotland diverge in terms of geographic spatiality, political systems and socio-cultural dynamics. Examination of divergence and convergence is an interesting way to highlight practice and provision deficits and disparities and is fundamental to the methodological principles of Interpretative Phenomenological Analysis (IPA). Scotland was chosen for this IPA study because researchers had direct access to essential EE networks and convincingly, Stam (2015) suggests that the quality of a regional EE ecosystem is a suitable test as an evaluation in determining the robustness of suitable study contexts and Cope (2005) details the power of phenomenology in entrepreneurship studies as a study method. Based on this rationale for contextual selection the study examines Entrepreneurial Education in Brazil using Scotland's developed entrepreneurship ecosystem as an approach to address our research question - how might Brazil advance EE models and improve access to quality education? We 
argue that there is lack of accessibility for Brazilians to experience entrepreneurship training particularly in the VE offerings, and subsequently less opportunities for individuals to gain higher level posts in Brazilian organisations. Access to knowledge and skill offers the most disadvantaged people in society opportunities to pursue better lives. This article contributes to an agenda that strives to improve opportunities for young Brazilians through better accessibility to EE. The following sections review literatures, firstly around theoretical underpinings to EE and secondly, Brazil and Scotland highlighting contextually, educational infrastructure, and poitical, social and cultual influences.

\section{Theoretical Underpinning in Enterprise and Entrepreneurship Education}

Pedagogical thinking continues to emerge and although there is consensus that supports students' need to learn in experiential and transformative ways (Neck and Corbett, 2018; QAA, 2018), there exists underdeveloped thinking in the basic philosophy of EE. Jones (2019) challenges educators to embrace a philosophy, 'pedagogical signature', in other words individuality should be the engine of EE; a philosophy of entrepreneurial agency and one that recognises the importance of inclusivity and accessibility for teachers and students. An approach Jones (2019) argues is a 'potentially powerful tool' and an enabling agency, but not prescriptive. Enterprise and Entrepreneurship Education (EEE) is one of the most effective ways of developing skills and creating an entrepreneurial and value-adding culture according to Rocha and Freitas (2014). The offer and availability of EE, nationally, is often policy driven in an attempt to stimulate economic and societal changes. Empowering people into valueadding activities, by creating new business, means an economy less dependent on fluctuations surrounding employment opportunities offered in the formal labour market (Lourenço, Taylor and Taylor, 2013; Rauch and Hulsink, 2015).

This study is particularly concerned with access to EE programs, by that we mean provision and the EE ecosystem that shapes implementation of innovative projects that enhance entrepreneurial skills in the workplace (Kozlinska, 2011; Vanevenhoven and Liguori, 2013; Agarwal, et al., 2020). Challenges regarding the implementation of EE in VE begins with an acknowledgement of the differing interpretations of definitions and concepts that appear to exist (Liguori et al., 2014). Conceptually, enterprise education and entrepreneurship education are underpinned by different pedagogies, expectations and outcomes (Katz 2003; Neck and Greene, 2011; Fayolle, 2013). Albeit they are often referred to as Enterprise and Entrepreneurship Education there are notable and relevant distinctions between the two. Therefore, definitional 
clarity is indeed important for educators, students, learners and all other relevant stakeholders in relation to application, delivery and expected outcomes. In the first instance, Enterprise Education is competency based and focusses on skills development, closely related to outcomes and outputs that create employability capacity. Comparatively, Entrepreneurship Education builds mind-sets, configured towards value creation and the potentiality of new venture creation. Most recently, QAA (2018), the UK's Higher Education Quality Assurance Agency (QAA) published working definitions for both concepts. Several decades ago, Gibb (1993) considered the two terms to be similar but recognised that use in different contexts results in the most obvious differences. For Kuratko (2005), entrepreneurship education is different from typical business education and given that business start-up and business management are different activities requiring different skills and mind-sets, then it is not an unsurprising conclusion. And in more recent times, Samwel-Mwasalwiba (2010) concurs that there is a conceptual difference between enterprise education and entrepreneurship education. Despite a rather prolonged and sometimes contested evolution, there is now a body of evidence that sets out a definitional consensus and creates academic legitimacy that EEE so desperately requires (QAA, 2018). Therefore, in relation to this study, the term entrepreneurial education (EE) is used to refer to initiatives and the broader application of teaching enterprise and entrepreneurship at the different levels of education.

Entrepreneurial education facilitates people's acquisition of entrepreneurship abilities though development of attitudes, skills, behaviours and personal attributes that are highly valued in the labour market; such as creativity, willingness to take risks, commitment, willpower to create new business (Guven, 2013; Thanasi-Boçe, 2020). As discussed by Smith and Paton (2014), the purpose of EE goes far beyond knowledge acquisition and equips students with a wide range of emotional, social and practical skills. And EE aims to develop multiple societal dimensions (Kozlinska, 2011), such as employability and entrepreneurship, and the development of entrepreneurial abilities aimed at improving the prospects of everyone in society.

Empirical studies which feature EE in VE, deal with the pedagogical practices and necessary instruments that excite students to learn about an entrepreneurial vocation (Ishiguro, 2015; Thompson and Kwong, 2016). Embedding EE into VE encourages entrepreneurial behaviour in students (Onstenk, 2003) and provides socio-economic benefits for those pursuing an entrepreneurial career (Guven, 2013; Behling and Lenzi (2019), and those learning enterprise skills for application in vocational contexts (Hietanen and Jarvi, 2015). Liguori (2018), Neck 
and Corbett (2018) and Kakouris and Liargovas, (2020), agree there has been notable growth in the number of EE studies which to a degree, they argue, is detrimental to the scholarship of EE that underpins what we actually 'know'. EE is widely accepted in the academic community as an attractive area of study, however those studies are fragmented; mentoring clubs, entrepreneurship programmes, systematic reviews and broader pedagogical and learning methods as well as context (Gibb 1993; Gibb and Hannon 2006; Neck and Greene, 2011; Leitch et al., 2012; Fayolle, 2013; Duval-Couetil, 2013; Pittaway et al., 2015). Most recently Kakouris and Liargovas, (2020) focus on the complexity and scholarly foundations of EE highlighting distinct deficits that exist in modes of $\mathrm{EE}$, but conclude there are four discrete modes, arguing that Vocational Education is taught through the 'for' mode, where individual and skills is the starting point of curriculum development with applied and experiential learning. It follows, there is scope to find out more about embedding EE in VE, specifically the role of human learning from a skills perspective and the experiential opportunities available in VE (Kolb, 1984; Minniti and Bygrave, 2001; Pittaway et al., 2015; Aamir et al., 2019; Grewe and Brahn, 2020; Moreira et al., 2020). As yet we do not fully understand the scholarly constructs that help us to know how EE is made accessible in a skills-based curriculum or how VE develops entrepreneurial learning through experiential opportunities, however we begin our examination in accordance with the principles of Interpretative Phenomenological Analysis, and specifically, sensitivity to context (Smith, 2011). The following section reviews literatures that examine infrastructure, political, cultural, economic and institutional influences in Brazil and Scotland.

\section{Study Context: EE Practices in Brazil and Scotland}

Historically, Ramos (2002) suggests a traditional position in the Brazilian labour market was grounded in identification of the type of qualification a worker possessed in order to undertake a particular job. Changes in the profile of workers and new ways of working only became more evident after the beginning of the globalization. In today's workplace vocational qualifications according to Ramos (2002) would become hardly applicable without the processes and practices of EE, given that entrepreneurial skills means providing workers with tools for performing in a business environment of low operation predictability and high complexity. Data from IBGE [Brazilian Institute of Geography and Statistics] (2019) revealed that, in Brazil, 39,8\% of enterprises continue to operate after 5 years. Regarding Brazilian education, the Organization for Economic Cooperation and Development (OECD, 2015) reported that in the year of 2013 only $61 \%$ of young people aged from 25 to 34 years had finish high school. In 
this age group, $76 \%$ were not studying. Of this $76 \%$, 52\% were working as employees in the formal labour market, and $20 \%$ of them were neither working nor studying.

Scotland, according to Office for National Statistics (2020) grew its economy 0,7\% in 2019 (less than $1 \%$ of UK as a hole) and unemployment stands at 3.8\% of the workforce (a positive rate when compared to Brazil's 12,2\% rate). Scotland has the third largest city in the UK, Glasgow, which has economic and political representation throughout the country, and has even lower unemployment rates (5.1\%). In most cases the Scottish educational model is designed for students to finish secondary education at the age of 16-18. After that, to continue their studies, students can choose between further education (a type of 'post-compulsory' education similar to the Brazilian VE) and higher education, i.e. universities (Andrew et. al., 2008; Husband and Jeffrey, 2016). In Scotland, about 90\% of universities and colleges offer EE (Mckeown et. al., 2006). Data reveals that $78 \%$ of secondary school graduates access Scottish VE, and $55.7 \%$ of college graduates progress to higher education (SFC, 2016). Universities are considered important institutional actors and pillars in the system of innovation (Passaro, Quinto and Thomas, 2018). However, it is important to highlight that understanding the historical and economical context of different countries is extremely relevant to conducting any kind of IPA on EE (Oostembeek, Praag and Ijsselstein, 2010).

In contrast to Brazil, Scotland tracks and monitors EE for instance, quality assurance in Scottish Education (McCulloch and Tett, 1996); the growth of academic and governmental interest on small and medium-sized enterprises, recommending investments in vocational and entrepreneurial further education (Andrew et al., 2008; Matlay, 2009); the use of information and communication technologies (ICT) in VE and Further Education (FE), (Mills and Whittaker, 2001); research policies in Scottish VE and FE (Grant and Edgar, 2003); methods of entrepreneurial teaching (Hegarty, 2006; McKeown et al.; 2006); collaborative models for education and program development (Comrie, 2011) and strategies to modernise VE training systems (Pilz and Canning, 2017). The challenges for Scottish VE institutions, according to Andrew et al., (2008), reside in monitoring industry changes, given that courses need to remain accessible and effective both in terms of training the workforce, value for money and assisting adult students who need training for dynamic labour markets. Markedly, Brazil VE attracts frequent discussion, especially by Ramos (2002), Kuenzer (2003, 2006, 2012), Ciavatta (2006), Frigotto (2007), Pacheco, Pereira and Sobrinho (2010) and Ciavatta and Ramos (2012). Kuenzer (2006) believes that the VE model being practiced in Brazil since the 1980's, is not 
efficient in terms of placing the students at high level positions in corporations, mostly inaccessible for those socially disadvantaged in society. For the scholar (ibid), Brazilian VE is effective only in terms of placing students at low-profile jobs; it affects students' permanence in the labour market with little concern for professional growth (Kuenzer, 2003, 2006). Notably, EE is emerging in Brazilian curriculum, demanded by society, the workplace and encouraged by governmental educational policies, in particular, by Brazilian Law of Guidelines and Bases - LDB (Brazil, 2014). The first experiences date from the 1930's with the creation of further education in institutions, namely SENAI, SENAC and SESC. Despite best efforts this 'new' model is clearly insufficient at meeting modern demands in the Brazilian economy and to Drewinski (2009), under the ideological point of view, EE presents two perspectives in terms of its possible developments. The first is based on the belief that this type of training can: ensure students' entry in the formal labour market by means of the first job; increase students' prospect of getting a steady job (leaving the informal economy); and foster personal, technical, and entrepreneurial development. The second perspective considers that the EE can contribute to: the creation of the new business; filling the gaps of the market; redirecting students who are not satisfied with the traditional model of education with regards to the construction of knowledge, abilities and skills that are necessary to a successful entrepreneurial performance, which is precisely the full conception entrepreneurship. In summary, provision and policy of $\mathrm{EE}$ in $\mathrm{VE}$ is underdeveloped, and requires investigation into pedagogical practices, EE provision and accessibility defined by context. The following section explains IPA principles, our interpretative processes and tests for rigor applied in this study.

\section{Methodology}

This IPA study examines Brazilian and Scottish policy and provision in entrepreneurial education, employing an interpretative qualitative research methodology with in-depth one-onone interviews. Sampling was purposive, existing academic networks in both countries were contacted to identify key persons from VE and national entrepreneurial ecosystems. Composed of 12 stakeholders, the sample included institution managers and professors of entrepreneurship from two educational institutions in Brazil (6), and two in Scotland (6). In Brazil, the chosen institutions are government-ruled and offer vocational education courses in the state of Paraná, where the research group is based. The two selected institutions in Scotland were identified by local entrepreneurial support bodies; Scottish Institute for Enterprise SIE and the Young Enterprise Scotland. All twelve interviewees met the following criteria for inclusion including 
different role profiles that would capture different experiences: (a) relevance of the position held in the institution, (b) knowledge of EE practices, (c) availability and willingness to participate; Figure 1 details interviewee profile.

Figure 1: Profile of the interviewees

\begin{tabular}{|c|c|c|}
\hline $\begin{array}{l}\text { Investigated } \\
\text { institutions }\end{array}$ & Interviewee & Role played \\
\hline \multirow{3}{*}{$\begin{array}{c}\text { Scottish } \\
\text { institution } 1\end{array}$} & Manager (SM1) & $\begin{array}{l}\text { Coordinator of the courses of fashion and designing - responsible for } \\
\text { the business incubator programme. }\end{array}$ \\
\hline & $\begin{array}{l}\text { External consultant } \\
\text { (supporting } \\
\text { institution) (SEC) }\end{array}$ & $\begin{array}{l}\text { External consultant responsible for supporting EE in all Glaswegian } \\
\text { colleges. Expert in the field of audio-visual productions. }\end{array}$ \\
\hline & Professor (SP1) & $\begin{array}{l}\text { Entrepreneur in the field of audio-visual productions and lecturer of } \\
\text { the investigated institution } 1 \text {. }\end{array}$ \\
\hline \multirow{3}{*}{$\begin{array}{c}\text { Scottish } \\
\text { institution } 2\end{array}$} & Manager (SM2) & $\begin{array}{l}\text { Coordinator of the department of creative industries in the biggest } \\
\text { institution of VE in Scotland. Had previous experiences in radio and } \\
\text { television working as a reporter. }\end{array}$ \\
\hline & $\begin{array}{l}\text { Executive } \\
\text { (supporting } \\
\text { institution) (SE2) }\end{array}$ & $\begin{array}{l}\text { Executive from the Scottish Institute for Enterprise. An institution } \\
\text { focused on the provision of input and basic materials to the teaching } \\
\text { of EE in colleges, universities and for young entrepreneurs. }\end{array}$ \\
\hline & Professor (SP2) & $\begin{array}{l}\text { Coordinator of Bridge to Business - a programme addressed to } \\
\text { providing the colleges with support regarding business planning. }\end{array}$ \\
\hline \multirow{4}{*}{$\begin{array}{l}\text { Brazilian } \\
\text { institution } 1\end{array}$} & Manager (BM1) & $\begin{array}{l}\text { Director of the biggest university campus in the Brazilian state of } \\
\text { Paraná. }\end{array}$ \\
\hline & Manager (BM2) & $\begin{array}{l}\text { Director of teaching and learning from the university campus of } \\
\text { Curitiba (Paraná). Lecturer of Entrepreneurship. }\end{array}$ \\
\hline & Professor (BP1) & $\begin{array}{l}\text { Lecturer of Entrepreneurship. Works with secondary education and } \\
\text { higher vocational education. }\end{array}$ \\
\hline & Professor (BP2) & $\begin{array}{l}\text { Lecturer of Enterprise and Management. Works with technical } \\
\text { secondary and higher education. Expert on technical distance } \\
\text { education. }\end{array}$ \\
\hline \multirow[t]{2}{*}{$\begin{array}{c}\text { Brazilian } \\
\text { institution } 2\end{array}$} & Manager (MB3) & $\begin{array}{l}\text { Former director of Community and Business Relations. Responsible } \\
\text { for the intellectual property and for developing strategies to the } \\
\text { provision of EE. }\end{array}$ \\
\hline & Professor (BP3) & $\begin{array}{l}\text { Lecturer of Entrepreneurship and Management in technical secondary } \\
\text { and higher education }\end{array}$ \\
\hline
\end{tabular}

Source: Prepared by the authors (2020).

Study design was based on the interpretative paradigm (Burrell and Morgan, 1979), and principles of phenomenology for data collection and analysis (Leitch, Hill and Harrison, 2010). In order to collect the empirical data relevant to this study, a semi-structured script was developed and questions clustered around literature based on EE phenomena and VE Context. 
Regarding the procedures, one-on-one interviews were conducted in person in Brazil and Scotland. All interviews were audio-recorded and subsequently transcribed verbatim. IPA is detailed examination of the experiences of a given person. It offers insights into how a given person, in a given context, makes sense of a given phenomenon. It has ontological and philosophical origins in phenomenology, hermeneutics and ideography (Smith, 2011). Rigor can be tested by applying Yardley's framework which involves attention to four broad principles: 'sensitivity to context; commitment and rigour; transparency and coherence; and impact and importance’ (Yardley, 2008).

IPA procedures involved, reading and rereading the transcripts with notes from managers and teachers' interviews. Topics emerged as we looked for ways to connect divergent and convergent interpretations of interviewee experiences and searching for contextual patterns between Brazil and Scotland framed the finding (Smith, Flowers and Larkin, 2009). Even though phenomenon was experienced by the interviewee not the interviewer, the interpretation of both, affects the research (double hermeneutics). IPA studies are concerned with the balance of convergence and divergence between cases, as well as indicating points on the paths where interpretation of investigator and investigated subject intersect (Smith, 2011). The following section presents findings and discussion of phenomena acknowledging the need for rigor through sensitivity to context, transparency of data, coherence of analysis and impact (Yardley, 2008).

\section{Findings and Discussion}

Scotland demonstrates having more experience formulating public policies for provision of EE, setting up educational goals, creating support agencies and monitoring the outcomes VE. Through interviews with Scottish stakeholders, it was possible to capture the vision that prevails in Scotland; that students should not only be trained for entering the labour market, but also encouraged to continue their studies. On course completion, students are expected to have gained skills to succeed in the labour market and become financially independent.

One of the Scottish interviewees highlighted that the regulatory institution SQA (Scottish Qualification Authority) makes the program (curriculum) inflexible and runs random tests to verify whether the contents are being properly delivered by the teachers and institutions. "The 
program is strongly influenced by the content of this document, and there is an examination that is performed to make sure that the contents are being taught" (Scottish Manager - SM1). Therefore, it is possible to understand that institutions need to apply the standards set by the SQA. Hence the importance of policy driving forward the enterprise agenda in order that it powerfully influences standards, accessibility and provision of entrepreneurship education and projected employment outcomes for those with skills and knowledge. Currently in Brazil, although policy suggests models for the application of EE exist, there are very few instruments and guidelines for its application. The 'age' of the institutions (the number of years they have) and their ideological position will have a great impact on the development of educational initiatives. Another aspect that affects the way EE is delivered is the degree of enthusiasm of teachers. Their degree of expertise, position in the institution, position in relation to other actors and their discourse are elements that constitute their legitimacy (Foliard, Le Pontois, Fayolle and Diermann, 2020).

According interviewee experiences, the ideological position of the Brazilian institutions in what concerns training, autonomy, and human emancipation (Pacheco, Pereira and Sobrinho, 2010) suggest a distance exists between, what is taught (the transmitted knowledge), and the needs of the market. Therefore, together with preparing students for the labour market, emancipation and people's independence, Brazilian managers believe VE should tackle social relationships that sit behind the phenomena (Ciavatta, 2006). Suggestions of human training and entrepreneurship present in one interview: "The student enters into the labour market, but that he/she has other options rather than only being inside a company. They need to be trained with the skills to perform their work also outside a company; opening their own business for instance” (Brazilian Manager - BM1).

The macro-organizational level, which comprises of political influences, has impact on Scottish institutions. In turn, the social context and infrastructure both influence and are influenced by the labour market. In Brazil, on the other hand, labour market needs provide institutions with general guidelines. In both contexts, political force influences and determines not only the social infrastructure but also the labour market. The influence of the government and other organisations in VE in Scotland is very well planned because it has to meet standards imposed by the financing body (Scottish Funding Council). In the Brazilian context, even though the financing agency is a government body (Secretary of Technological Education - SETEC-MEC), institutions have a greater autonomy in what concerns the planning and management of the VE 
program, the development of courses, and the adoption of methods and teaching practices. One of the Brazilian interviewees commented, the Brazilian government should have a stronger influence and control over the institutions to ensure that results expected from the provision of EE are being achieved. His criticism about the government is based on the fact that it "does not take into account the percentage of employability of the graduates" (Brazilian Manager - BM3)

In terms of the institutional dimension, EE projects focused on employer and employee demand, are more strongly driven by Scottish government than Brazilian government and notably, the pressures on internal policies are: political influence, social infrastructure and the labour market. Educational managers from support agencies lack familiarity with entrepreneurial teaching practices and innovative methods in the Scottish institutions, the educational managers' responsibility is supplying more practice-based methods, Scottish Manager 2, “what changes is the way in which contents are delivered, the students' expectations, enthusiasm, but essentially it is the same thing." Brazilian managers show more awareness and engagement with the activities and innovative practices of entrepreneurial teaching. BM1 reports that the inclusion of EE in the courses targets the development of entrepreneurial and personal skills, which can be categorised as transferable skills (Smith and Paton, 2014). The interviewee also points out that [...] students begin to see entrepreneurship not only as the act of setting up a business, but also as an activity that is present in almost everything, such as in intrapreneurship or social entrepreneurship [...] [activities] where they should know how to manage and have innovative ideas (Brazilian Manager - BM1).

In Scottish institutions, teacher training is a daily practice. Training, frequently available, is aimed at pedagogical support staff and teachers, although participation is not compulsory. Scottish Manager highlights that [...] these courses are very common in the institutions, but teachers are not very committed to their attendance. [...] the funding bodies should keep track of these activities to ensure the participation of teachers and staff (Scottish Manager - SM1). Alternatives for training needs were presented by participant SP2, who reported that the institution provides support to teachers (Scottish Institute for Enterprise and Young Enterprise Scotland); "we make teachers come to us and ask them what they need, and how can we develop specific projects" (Scottish Professor 2). In contrast, the Brazilian institutions, show differences regarding $\mathrm{EE}$ teacher training. Interviewees from institution 1 stated that teachers are responsible for their EE training, while interviewees from institution 2 said the institution promotes "some training meetings and workshops, to make people go there, not only 
entrepreneurship teachers, but all the professional education staff” (Scottish Manager - SM2). However, it was observed that the generation of teachers working in Vocational Education graduated in the 1980s or 1990s, which means that, many of them, are not up-to-date with advances in new technologies: "there is a need for awareness (...) workshops, courses, and lectures aimed at encouraging participation in entrepreneurship events” (Brazilian Manager BM1).

Methodological deficiencies were frequently mentioned in interviews. SM2 warned us about 'glamorization' of the entrepreneur's activity, meaning that some students do not want to start their careers in bottom position in companies, i.e. doing the hard work. The curriculum inflexibility identified in Scottish education is perceived as an obstacle to creativity: "teachers need to stick to the activities pre-established in the curricula, which prevents them from having more time and opportunity to develop creative activities with their students" (Scottish Manager - SM1). In Brazil, structural and methodological deficiencies are compensated by the individual action of instructors and managers who are passionate about EE, even when training for entrepreneurship teaching is considered deficient (Stadler and Smith, 2017). It is these deficiencies that affect accessibility to high quality provision throughout Brazil with nonstandard delivery of essential entrepreneurial skills and knowledge (Kuenzer, 2006; 2012). The main methodological deficiencies reported in the interviews were: insufficient articulation between work and school, poor infrastructure (e.g. lack of facilities and equipment), lack of practical activities, lack of appropriate speech to inspire students (motivational speech), lack of partnerships with external institutions (mainly observed in Brazil); lack of teachers committed to teaching of entrepreneurship.

Reflection as a teaching practice was not found in the investigated Scottish institutions, given that VE is characterised by teaching of practical skills and know-how abilities. According to Brazilian Professor - BP3 “[in Scotland] reflective topics are approached in higher education and undergraduate university courses". In Brazil, it is up to teachers to decide whether to include reflective activities in their classroom or not. To BP1, "the teaching method must be reflective and differentiated" and adds that his/her "goal has been to foster reflection opportunities in the classroom and encourage students' participation" (BP1).

Scottish interviewees reported that their programme of education is designed in accordance with stakeholders' demands. Scottish manager - SM2 mentioned the difficulty of inserting entrepreneurial content in professional courses; and, in a critical tone, referred to this type of 
content as a fad: [...] but it is hard to talk about entrepreneurship in the middle of a discipline of physics or chemistry, and this is very bad. Why put in the curriculum what I cannot achieve academically? This is a fad and does not apply to all fields. (SM2).

In Brazil, the smallest influence of external organisations (low participation of SEBRAE in the VE institutions) and the strong economic impacts on targeting the labour market in teaching practices, shape the offer and provision of EE (Xavier-Oliveira, Laplume and Pathak, 2015; Behling and Lenzi, 2019). As opposed to the education institutions that seek in the social and market needs elements for the development and opening of courses, Brazilian institution 1 is not open to dialogue with other institutions or the society. BM1 revealed "it is the teachers' own expertise that determines the development and opening of courses, rather than the needs of the society or the institution itself" (Brazilian Manager - BM1). The relationship among the dimensions of the institutional level in the investigated institutions is demonstrated in Figure 2.

Figure 2 - Themes that shape the practice of entrepreneurial teaching in Scotland and Brazil

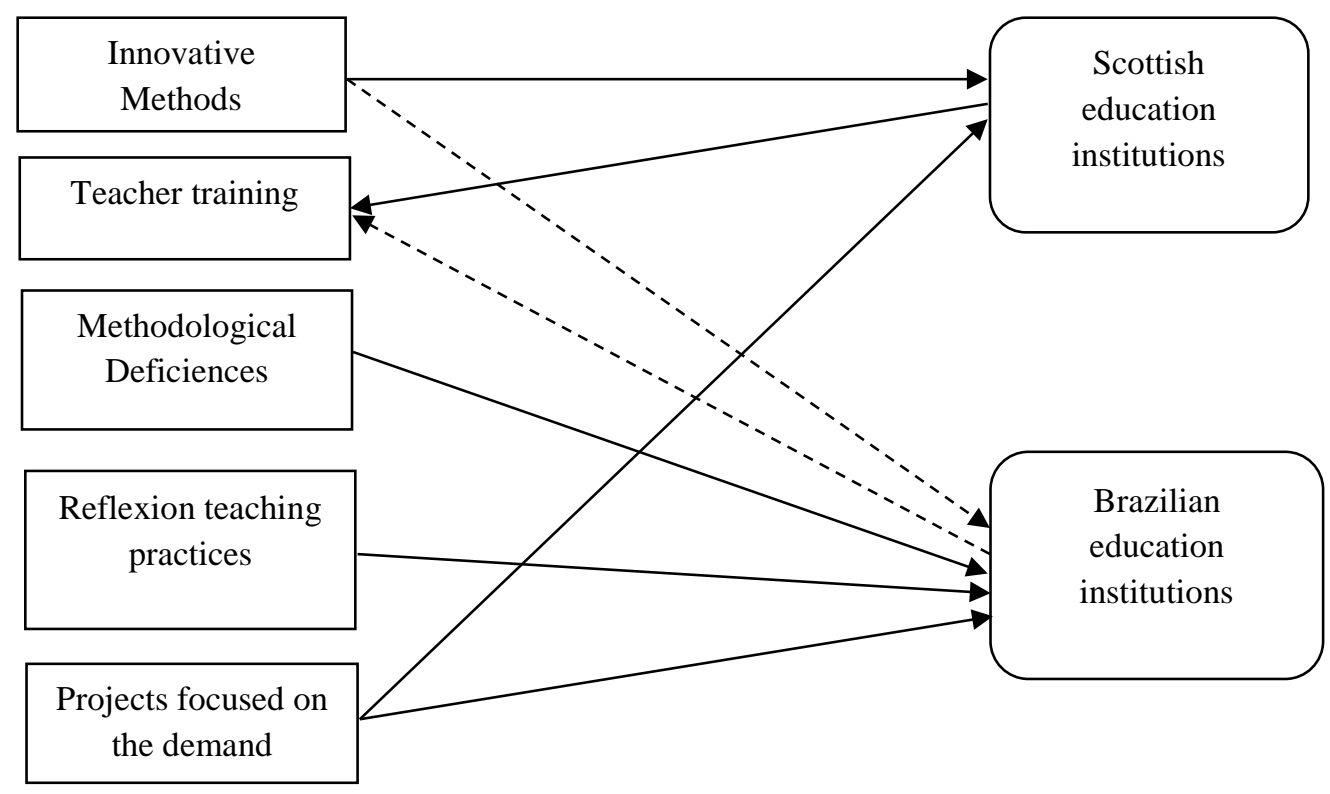

* Dashed lines indicate low relationship between categories Source: Prepared by the authors (2020).

Figure 2 summarises the analysis and demonstrates how themes, according to the interviewees, relate to one another. The dashed line between Brazil and teacher training, draws the attention to a subject deficiency in EE, and the weak relationship between innovative methods and Brazilian educational institutions. There is no relationship between methodological deficiencies 
and reflection practices in Scotland; themes that did not appear in the interviews or were not relevant to the analysis.

Pedagogical and entrepreneurial learning featured a notable emerging theme 'school support for the entrepreneurial student'. Curricular inflexibility and predictability in relation to results were high, and one could even say that students are approached in a 'patronised" manner by the teachers and institutional support (Castilo-Vergara and Alvarez-Marin, 2016). To SP2, the learning processes "are more linked to the ways in which students feel some content". Interviewees experiences from Scottish institution 1 reinforced the idea that the learning process takes place 'through' development of business plans and fairs, where there are presentations of practical work developed by the students themselves (Kempster and Cope, 2010). The process of learning 'through' practice and in the work environment is addressed by Rae (2004) and identified by one of the interviewees. SP2, who besides being an entrepreneur is a teacher, corroborated the idea of practical learning proposed by Pittaway and Thorpe (2012) by stating: "I have my own company, so I can hire some of my students to make content research and edit audio and video materials" (Scottish Professor - SP2). One of the Brazilian interviewees stressed that the learning process should match the profile and needs of students. To him/her, it is necessary to "adapt the content to student's profile and consider teaching through practice, especially given that nowadays our students can easily have access to all sources of theoretical content" (BP2). The concern with the learning process is very useful in the design of teaching methods, as BM3 points out [...] When we see that students need to have certain knowledge, for instance leadership and management, to have a good performance in the compulsory internship in the end of the course, we change the curriculum to address the issue. (Brazilian Manager - BM3)

Brazilian institution 2 has over one hundred years of existence in education, developing entrepreneurship programmes since 1997. The conceptual and technical 'maturity' of the institution became evident in the interviewee experiences. BP2 reported his/her experience in teaching of entrepreneurship in distance education, where teaching methods are inflexible and predictable, and classes follow a predetermined script: I think it is possible to do in person what is done in distance learning, and it would be very important. I hear people talking about interdisciplinary, for example, but I do not see it happening in practice (BP2). 
The analysis of the interviewee experiences suggests that teaching entrepreneurship as a compulsory activity leads to more effective results, SM2 mentioned that "the assessment of learning is given through the assessment of the institution, provided by the external bodies and funding agencies". Interviewees from the Brazilian institutions expressed that it is up to the teachers to decide whether to assess the learning or not. Likewise, the quality and complexity of assessment method employed is determined by teachers' academic and pedagogical training. According to SP1: [...] with the current assessment practices of our current education system, I do not see how they can evaluate, either because they are sometimes unfair, or because they are unable to represent the knowledge of the evaluated (Scottish Professor - SP1).

Through interpretative processes of interview experiences, it was possible to infer the assessment of learning is enhanced in Brazil, the experience of the idealistic Brazilian educator makes it possible to put into practice what is innovative, in this case, the assessment of learning. Lima et al., (2015) emphasize that improvement of the EE offer will occur through the use of methods with an emphasis on practice and direct contact between students and entrepreneurs. The schools' support for the entrepreneur student was an emerging theme, evident in narratives of the Brazilian and Scottish experiences. The recurrence of this theme attracted researchers' attention to the role that teachers play as supporters, who encourage students with entrepreneurial intent. In Scotland, it was possible to notice that educational institutions have a developed environment in terms of student support; evidenced by the existence of incubators, internship programs and pedagogical resources for teaching entrepreneurship. To SM1 "the educational institution brings an extra help for those who already have market experience”. Likewise, those part-time teachers who were/are entrepreneurs are inspiration for their students (Stadler and Smith, 2017).

In the Brazilian context, institution 1 is deficient in its projects and actions focused on teaching entrepreneurship, the theme is nothing more than institutional rhetoric, without the depth of the theme and without expressive projects in the area, as stated by BM1: [...] the role of the institution is to train students, make teachers aware of the importance [of training students], create spaces to support the entrepreneurial student. This student who wants to be an entrepreneur and seeks partnerships with the private sector and with the social organizations that support entrepreneurship (BG1). Nonetheless, interviewees from the Brazilian institution 2 reported experiences from two major projects (incubator and a technological business hotel) that work as spaces to support entrepreneurship. To BM3, the collaborative environment is only 
effective if the teacher is involved and "participates in events and is interested to learn about new technologies". This interviewee was celebrating the grant of four patents for products developed in his/her discipline: "many students came to thank me for granted patents! I want to make a difference in their lives” (Brazilian Professor - BP3).

The experiences of interviewees are collated in the following interpretation of convergent and divergent phenomenological relationships, Figure 3.

Figure 3 - Relations between VE and EE for educational institutions

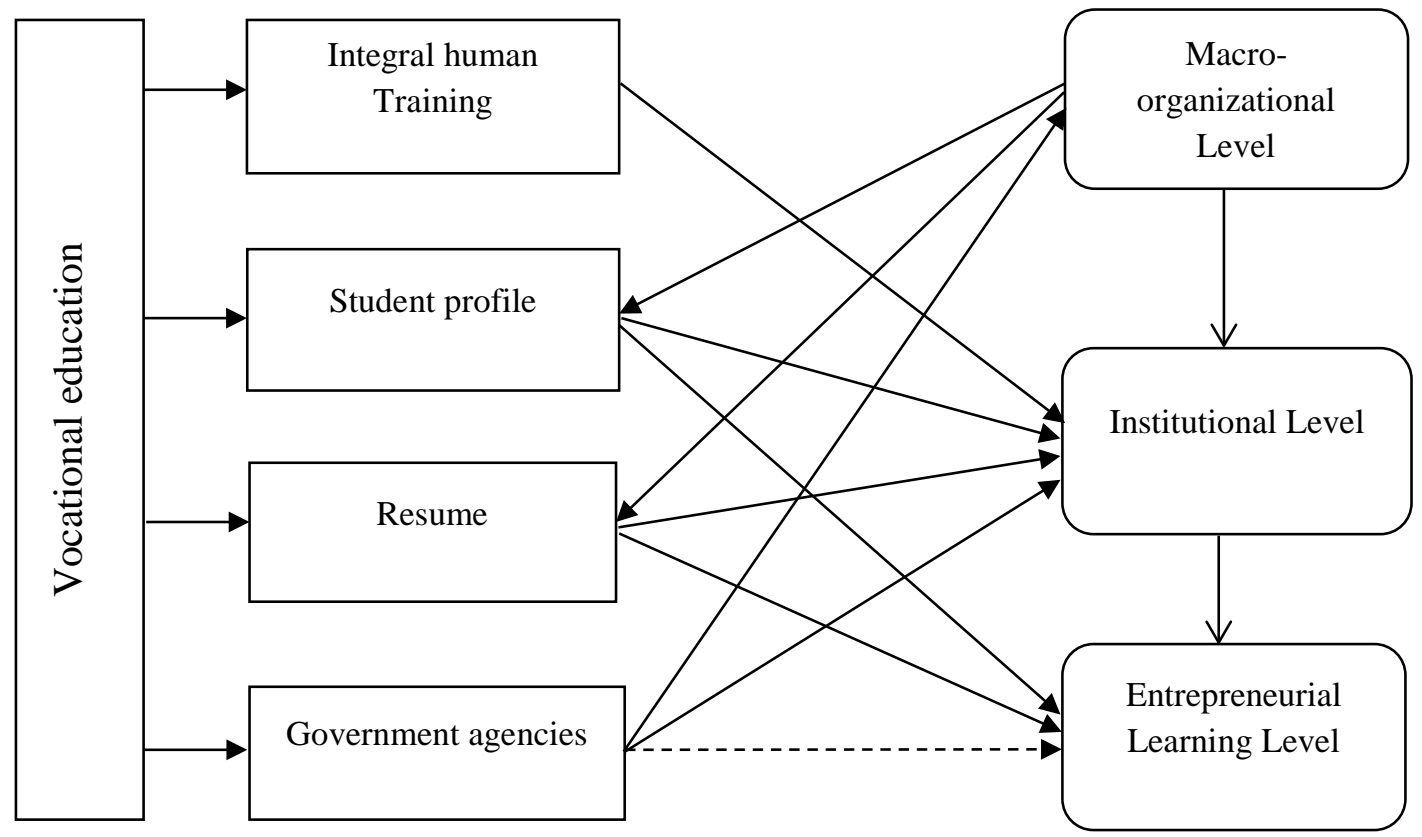

* dashed lines indicate low relationship between categories.

Source: Prepared by the authors (2020).

The governmental bodies, funders of the education systems, in both cases have an impact on all categories, except in entrepreneurial learning in Brazil; Scottish Government finances the entities that give pedagogical support to entrepreneurship teaching in colleges. In contrast, the only EE category that impacts VE is the macro-organizational dimension, which is capable of influencing both the profile of graduates and program (Deitos and Lara, 2016). It is possible to conclude, that Scotland, being a developed country, and with EE educational policies implemented for a long time, can inform advances to EE in VE in Brazil. This study did not seek to make comparisons between these nations, but to understand the experience and successful practices of one country and how that knowlege might inturn create more opportunities for individuals to gain higher level posts in Brazilian organisations. Our final 
remarks respond to our research question by explaining how accessibility to EE provision in VE might be advanced in Brazil

\section{Final Remarks}

We set out to examine accessibility of EE provision in VE and how it might be advanced in Brazil. According to Bendickson (2011, p 538-539), 'better understanding and subsequently improving conditions for entrepreneurs should be the foundation for nearly all of our research [...] topics and phenomena that truly assist entrepreneurs in their endeavors”. We discovered that for Brazilians to experience entrepreneurship education, provision is based solely on passion and interests of educators and not driven by policy. There are indeed fewer opportunities for individuals to gain higher level posts in Brazilian organisations because they have underdeveloped enterprise skills. Moreover, fragmented provision of EE, offers less support to those individuals with entrepreneurial aspiration, these findings contribute to the overall position that provision of Entrepreneurship Education in VE in Brazil can be enhanced with greater access to teaching and learning oportuniunities and with clear policy statements on implemetation. Results suggest the current model in Brazil is too narrowly focused on skills development, generally in low-profile and predictable jobs. Evidently, EE in Brazil is much more concerned with the needs of the formal labour market than supporting student aspirations, which ultimately hinders the formation of new entrepreneurs and high achievers. IPA, the method of data analysis, made it possible to highloght and understand convergences and divergences between two educational models, and is noted that Interpretative Phenomenological Analysis is relatively unexplored in Brazilian studies, especially in the business management field adding further contribution to literature.

Based on our examination, it can be concluded that Brazil has scope to improve political, institutional and inter-organizational structure, as well as increase interaction between institutions, community and external bodies capable of fostering EE in VE. For Brazil to develop next generation talent and offer programmes that support employability, then EE requires attention from policy makers and a national EE strategy, developing an entrepreneurial ecosystems of instituions and partners (Stam 2015). This examination exposes the idea that EE is integral an development of the VE labour market and underpin enhanced opportunities that improve accessibility of higher paid posts for VE graduates in Brazilian organisations. For many countries, rethinking how students and workers prepare for the job market means 
redefining an inclusive and accessible society for citizens. Therefore, it is possible to view entrepreneurial education in VE as an opportunity for increasing economic development, improving wealth generation, and sustaining social development through the companies and businesses created by the entrepreneurs (Schumpeter, 1982; Flory, Andreassi and Teixeira, 2013; Rideout and Gray, 2013; Santos, Silva and Lopes, 2016).

Contributions from the Scottish experience bring useful recommendations for Brazilian entrepreneurial education, such as greater support from external institutions in education, both in terms of pedagogical support, production of didactic materials, training of teachers, as well as structural investment for schools. Better informed educational policies could also clearly define the entrepreneurial skills Brazil's future workforce needs, at primary, secondary and higher education levels. Finally advances are possible through improved entrepreneurial ecosystems.

Future research might address EE in Brazil using different research methods; qualitative and quantitative. Further studies between teachers and students in VE, designed to evaluate the efficacy of methods and strategies of teaching and provision of learning environments for new entrepreneurs, in formal education and for lifelong learning. Finally, understand EE in different technological areas (Kakouris and Liargovas, 2020), and in countries with distinct socioeconomic profiles, however the central argument is the importance of government policy, irrespective of context, which prepares students for entrepreneurial leadership roles as well as supporting creation and management of new ventures.

\section{REFERENCES}

Aamir, S., Atsan, N.F. and Erdem, A.F. (2019), "A review of entrepreneurship education research in the special issues of Education + Training journal", Education + Training, Vol. 61 No. 9, pp. 1078-1099.

Agarwal, S., Ramadani, V., Gerguri-Rashiti, S., Agrawal, V. and Dixit, J.K. (2020), "Inclusivity of entrepreneurship education on entrepreneurial attitude among Young community: evidence from India", Journal of Enterprising Communities: People and Places in the Global Economy, Vol. 14 No. 2, pp. 299-319. 
Andrew, A., Murning, I., Pitt, M. and Tucker, M. (2008), "Investment in the Scottish further education estate 1999-2006”, Journal of Financial Management of Property and Construction, Vol. 13 No. 3, pp. 209-216.

Behling, G. and Lenzi, F.C. (2019), “Competências Empreendedoras e Comportamento Estratégico: um Estudo com Microempreendedores em um País Emergente”, BBR Brazilian Business Review, Vol. 16 No. 3, pp. 255-272.

Bendickson, J. (2021), "Building entrepreneurship research for impact:Scope, phenomenon, and translation”, Journal of Small Business Management, Vol. 59 No. 4, 535-543, DOI: 10.1080/00472778.2021.1905822

Brazil, (2014), "Lei no 9.394, de 20 de dezembro de 1996. LDB - Lei de Diretrizes e Bases da Educação Nacional”, Diário Oficial da União, Brasília, DF.

Brunetti, I. and Corsini, L. (2019), "School-to-work transition and vocational education: a comparison across Europe", International Journal of Manpower, Vol. 40 No. 8, pp. 1411-1437.

Burrell, G. and Morgan, G. (1979), Social paradigms and organizational analysis. Aldershop, Gower: Routledge.

Ciavatta, M. (2006), “Os Centros Federais de Educação Tecnológica e Ensino Superior: duas lógicas em confronto”, Educ. Soc., Vol. 27 No. 96, pp. 911-934.

Ciavatta, M., and Ramos, M. (2012), "Ensino Médio e Educação Profissional no Brasil: dualidade e fragmentação”, Retratos da Escola, Vol. 5 No. 8, pp. 27-41.

Comrie, A. (2011), "Future models of higher education in Scotland: Can collaborative, technology-enhanced learning offer solutions?" Campus-Wide Information Systems, Vol. 28 No. 4, pp. 250-257.

Cope, J. (2005), "Researching entrepreneurship through phenomenological inquiry philosophical and methodological issues”, International Small Business Journal, Vol. 23 No. 2, pp. 163-189.

Deitos, R.A. and Lara, A.M.B. (2016), "Educação profissional no Brasil: motivos socioeconômicos e ideológicos da política educacional”, Revista Brasileira de Educação, Vol. 21 No. 64, pp. 165-188.

Drewinski, J.M.A. (2009), “Empreendedorismo: o discurso pedagógico no contexto do agravamento do desemprego juvenil”, UFPR - Universidade Federal do Paraná, Curitiba PR.

Duval-Couetil, N. (2013), “Assessing the impact of entrepreneurship education programs: Challenges and approaches”, Journal of Small Business Management, Vol. 51 No. 3, pp. 394-409. 
Fayolle, A. (2013), "Personal views on the future of entrepreneurship education”, Entrepreneurship \& Regional Development, Vol. 25 No. 7, pp. 692-701.

Flory, H.; Andreassi, T. and Teixeira, A M.A.C. (2013), "Políticas públicas de empreendedorismo para a população de baixa renda: transformando necessidades em oportunidades”, Cadernos Gestão Pública e Cidadania, Vol. 19 No. 62, pp. 20-38.

Foliard, S., Le Pontois, S., Fayolle, A. and Diermann, I. (2020), “A Legitimidade De Professores Na Educação Em Empreendedorismo: O Que Podemos Aprender De Uma Revisão De Literatura”, REGEPE - Revista de Empreendedorismo e Gestão de Pequenas Empresas, Vol. 9 No. 1, pp. 98-123.

Frigotto, G. (2007), “A relação da educação profissional e tecnológica com a universalização da educação básica”, Educação \& Sociedade, Vol. 28 No. 1, pp. 1129-1152.

Gibb, A. (1993), "Enterprise culture and education understanding enterprise education and its links with small business, entrepreneurship and wider educational goals”, International Small Business Journal, Vol. 11 No. 3, pp. 11-34.

Gibb, A. and Hannon, P. (2006), “Towards the entrepreneurial university”, International Journal of Entrepreneurship Education, Vol. 4 No. 1, pp. 73-110.

Grant, K. and Edgar, D. (2003), "Using the theory of policy networks and communities to explore who determines the Scottish higher education research policy: issues for educational managers”, International Journal of Educational Management, Vol. 17 No. 7, pp. 318-329.

Grewe, U. and Brahm, T. (2020), "Development of entrepreneurial competences in minicompanies at schools", Education + Training, Vol. 62 No. 7/8, pp. 917-931. https://doi.org/10.1108/ET-08-2019-0186.

Guven, S. (2013), “Determining vocational education undergraduate student's educational needs for entrepreneurship”, International Journal of Academic Research, Vol. 5 No. 3, pp. 379-383.

Hegarty, C. (2006), “It's not an exact science: teaching entrepreneurship in Northern Ireland”, Education + Training, Vol. 48 No. 5, pp. 322-335.

Hietanen, L. and Järvi, T. (2015), “Contextualizing entrepreneurial learning in basic and vocational education”, Journal of Enterprising Communities: People and Places in the Global Economy, Vol. 9 No. 1, pp.45-60.

Husband, G. and Jeffrey, M. (2016), “Advanced and higher vocational education in Scotland: recontextualising the provision of HE in FE”, Research in Post-Compulsory Education, Vol. 21 No. 1-2, pp. 66-72.

IBGE, INSTITUTO BRASILEIRO DE GEOGRAFIA E ESTATÍSTICA. (2019), Demografia das empresas e estatísticas de empreendedorismo. Rio de Janeiro, 121p. Available at: 
https://biblioteca.ibge.gov.br/index.php/bibliotecacatalogo?view=detalhes\&id=2101671

Ishiguro, J. (2015), "What Influences Entrepreneurial Career Choice?: An Exploratory Analysis of the Sally Caird's Get2 for Japanese High School Students", Academy of Entrepreneurship Journal, Vol. 21, No. 1, pp. 44-2015.

Jones, C. (2019), "A signature pedagogy for entrepreneurship education", Journal of Small Business and Enterprise Development, Vol. 26 No. 2, pp. 243254. https://doi.org/10.1108/JSBED-03-2018-0080

Jung, K., Eun, J.H., and Lee, S.H. (2017), Exploring competing perspectives on governmentdriven entrepreneurial ecosystems: lessons from Centres for Creative Economy and Innovation (CCEI) of South Korea. European Planning Studies, Vol. 25 No. 5, pp. 827847.

Kakouris A, and Liargovas P. (2021), "On the About/For/Through Framework of Entrepreneurship Education: A Critical Analysis” Entrepreneurship Education and Pedagogy, Vol. 4 No. 3 pp. 396-421. doi:10.1177/2515127420916740.

Katz, J.A. (2003), The chronology and intellectual trajectory of American entrepreneurship education: 1876-1999. Journal of Business Venturing, Vol. 18 No. 2, 283-300.

Kempster, S. and Cope, J. (2010), "Learning to lead in the entrepreneurial context", International Journal of Entrepreneurial Behavior \& Research, Vol. 16 No. 1, pp. 534.

Kozlinska, I. (2011), “Contemporary approaches to entrepreneurship education”, Journal of Business Management, Vol. 4, pp. 205-220.

Kuenzer, A.Z. (2003), "As relações entre conhecimento tácito e conhecimento científico a partir da base microeletrônica: primeiras aproximações”, Educar em Revista, Special Issue, pp. 43-69. https://doi.org/10.1590/0104-4060.299

Kuenzer, A.Z. (2006), "Educação profissional nos anos 2000: a dimensão subordinada das políticas de inclusão”, Educ. Soc, Vol. 27 No. 96, pp. 877-910.

Kuenzer, A.Z. (2012), "EM e EP na produção flexível: a dualidade invertida”. Retratos da Escola, Vol. 5 No. 8, pp. 43-55.

Kuratko, D.F. (2005), “The emergence of entrepreneurship education: Development, trends, and challenges”, Entrepreneurship theory and practice, Vol. 29 No. 5, pp. 577-598.

Kolb, D.A. (1984), Experiential learning: Experience as the source of learning and development. Englewood Cliffs, NJ: Prentice Hall.

Lackéus, M. (2020), "Comparing the impact of three different experiential approaches to entrepreneurship in education", International Journal of Entrepreneurial Behavior \& Research, Vol. 26 No. 5, pp. 937-971. https://doi.org/10.1108/IJEBR-04-2018-0236 
Leitch, C.M., Hill, F.M. and Harrison, R.T. (2010), "The philosophy and practice of interpretivist research in entrepreneurship: Quality, validation, and trust”, Organizational Research Methods, Vol. 13 No. 1, pp. 67-84.

Leitch, C.; Hazlett, S. and Pittaway, L. (2012), "Entrepreneurship education and context”, Entrepreneurship \& Regional Development, Vol. 24 No. 9-10, pp. 733-740.

Liguori, E., Corbin, R., Lackeus, M., and Solomon, S.J. (2019), "Under-researched domains in entrepreneurship and enterprise education: primary school, community colleges and vocational education and training programs", Journal of Small Business and Enterprise Development, Vol. 26 No. 2, pp.182-189. https://doi.org/10.1108/JSBED-04-2019-402.

Liguori, E., Winkler, C., Winkel, D., Marvel, M.R., Keels, J.K., van Gelderen, M., Noyes, E. (2018), The entrepreneurship education imperative: Introducing EE\&P. Entrepreneurship Education and Pedagogy, Vol. 1 No. 1, pp. 5-7.

Lima, E.; Lopes, R. M.; Nassif, V. and Silva, D. (2015), "Opportunities to Improve Entrepreneurship Education: Contributions Considering Brazilian Challenges.” Journal of Small Business Management, Vol. 53 No. 4, pp. 1033-1051. DOI: 10.1111/jsbm.12110.

Lourenço, F., Taylor, T.G. and Taylor, D.W. (2013), "Integrating 'education for entrepreneurship' in multiple faculties in 'half-the-time' to enhance graduate entrepreneurship”, Journal of Small Business and Enterprise Development, Vol. 20 No. 3, pp. 503-525.

Matlay, H. (2009), "Entrepreneurship education in the UK: A critical analysis of stakeholder involvement and expectations”, Journal of Small Business and Enterprise Development, Vol. 16 No. 2, pp. 355-368.

McCulloch, K. and Tett, L. (1996), "Performance indicators as quality assurance: the Scottish Community Education PI scheme”, Quality Assurance in Education, Vol. 4 No. 3, pp. 17-26.

Mckeown, J., Millman, C., Reddy, S., Smith, K. and Martin, L.M. (2006), “UK graduate entrepreneurship education in England, Wales, and Scotland”, National Council for Graduate Entrepreneurship Working Paper Series. UK.

Medeiros, V., Marques, C., Galvão, A.R. and Braga, V. (2020), "Innovation and entrepreneurship as drivers of economic development: Differences in European economies basedon quadruple helix model", Competitiveness Review, Vol. 30 No. 5, pp. 681-704. https://doi.org/10.1108/CR-08-2019-0076

Mills, V. and Whittaker, S. (2001), "Work based learning in Scottish Higher Education: policy and practice”, The Learning Organization, Vol. 8 No. 2, pp. 64-69.

Minniti, M. and Bygrave, W. (2001), “A dynamic model of entrepreneurial learning”, Entrepreneurship: Theory and Practice, Vol. 25 No. 3, pp. 5-25. 
Moreira, M.A., Alves, N.J.F., Andreassi, T. and Braga, JG.R. (2020), "Educação Empreendedora em Contabilidade: da Teoria à Aprendizagem Experiencial”, Revista Catarinense da Ciência Contábil, Vol. 19 No. 1, pp. 1-18.

Neck, H.M., \& Corbett, A.C. (2018). The scholarship of teaching and learning entrepreneurship. Entrepreneurship Education and Pedagogy, Vol. 1 No.1, pp. 8-41.

Neck, H.M., Greene, P.G. (2011). Entrepreneurship education: Known worlds and new frontiers. Journal of Small Business Management, Vol. 49 No. 1, pp. 55-70.

OECD (2015), Organisation for Economic Co-operation and Development. Education at a Glance 2015: OECD Indicators. Available online at: ttps://www.oecd.org/brazil/Educationat-a-glance-2015-Brazil-in-Portuguese.pdf

Office for National Statistics (2020), “Employment and Labour Market.” Available at: https://www.ons.gov.uk/employmentandlabourmarket.

Oliveira, R. (2015), "Precarização do trabalho: a funcionalidade da educação profissional”, Revista Diálogo Educacional, Vol. 15, No. 44, pp. 245-266.

Onstenk, J. (2003), “Entrepreneurship and Vocational Education”, European Educational Research Journal, Vol. 2 No. 1, pp. 74-89.

Pacheco, E.M.; Pereira, L.A.C. and Sobrinho, M.D. (2010), "Os Institutos Federais de Educação, Ciência e Tecnologia: limites e possibilidades”, Linhas Críticas, Vol. 16 No. 30, pp. 71-88.

Passaro, R., Quinto, I. and Thomas, A. (2018), "The impact of higher education on entrepreneurial intention and human capital”, Journal of Intellectual Capital, Vol. 19 No. 1, pp. 135-156.

Pilz, M. and Canning, R. (2017), "The modularisation approach of work-based VET in Scotland", Journal of Education and Work, Vol. 30 No. 7, pp. 722-730. $\underline{10.1080 / 13639080.2017 .1383095}$

Pittaway, L. and Cope, J. (2007), “Entrepreneurship Education: A Systematic Review of the Evidence”, International Small Business Journal, Vol. 25 No. 5, pp. 479-510.

QAA. Quality Assurance Agency. (2018), Enterprise and entrepreneurship education: Guidance for UK higher education providers. Avalilable at: https://www.qaa.ac.uk/docs/qaas/enhancement-and-development/enterprise-andentrpreneurship-education-2018.pdf?sfvrsn=15f1f981_8

Rae, D. (2004), “Entrepreneurial learning: a practical model from the creative industries”, Education+ training, Vol. 46 No. 8-9, pp. 492-500.

Ramos, M.N. (2002), A pedagogia das competências: autonomia ou adaptação? Cortez, São Paulo, SP. 
Rauch, A. and Hulsink, W. (2015), "Putting entrepreneurship education where the intention to act lies: An investigation into the impact of entrepreneurship education on entrepreneurial behavior”, Academy of Management Learning \& Education, Vol. 14 No. 2, pp. 187-204.

Rideout, E.C. and Gray, D.O. (2013), "Does entrepreneurship education really work? A review and methodological critique of the empirical literature on the effects of university-based entrepreneurship education”, Journal of Small Business Management, Vol. 51 No. 3, pp. 329-351.

Rocha, E.L.C. and Freitas, A.A.F. (2014), “Avaliação do ensino de empreendedorismo entre estudantes universitários por meio do perfil empreendedor”, Revista de Administração Contemporânea, Vol. 18 No. 4, pp. 465-486.

Samwel-Mwasalwiba, E. (2010), "Entrepreneurship education: a review of its objectives, teaching methods, and impact indicators”, Education + Training, Vol. 52 No. 1, pp. 2047.

Santos, A.M.F., Silva, B.M.L. and Lopes, A.O.B. (2016), "Educação empreendedora em Cursos Técnicos de um campus de um Instituto Federal do Nordeste do Brasil”, In: Anais XL Encontro da ANPAD 2016. Costa do Sauípe, BA.

Scotland Can Do. (2021), “A national vision \& approach to accelerating entrepreneurship and innovation”, Available at: https://cando.scot/about-us/ (accessed 12 august 2021).

Scottish Funding Council. (2016), "Reports and statistics." Available at: $<$ http://www.sfc.ac.uk/PublicationsStatistics/PublicationsStatistics.aspx>.

Schumpeter, J.A. (1982). Teoria do Desenvolvimento Econômico. Ed. Nova Cultural, São Paulo, SP.

Smith, A.M.J. and Paton, R.A. (2011), "Delivering enterprise: A collaborative international approach to the development, implementation and assessment of entrepreneurship”, International Journal of Entrepreneurial Behavior \& Research, Vol. 17 No. 1, pp. 104118.

Smith, A.M.J. and Paton, R.A. (2014), "Embedding enterprise education: A service based transferable skills framework”, The International Journal of Management Education, Vol. 12 No. 3, pp. 550-560.

Smith, J.A. (2011), "Evaluating the contribution of interpretative phenomenological analysis”, Health psychology review, Vol. 5 No. 1, pp. 9-27.

Smith, J.A., Flowers, P. and Larkin, M. (2009), Interpretative Phenomenological Analysis: Theory, Method and Research, Sage, London, UK. 
Stam, E. (2015), “Entrepreneurial Ecosystems and Regional Policy: A Sympathetic Critique”, European Planning Studies, Vol. 23 No. 9, pp. 1759-1769. 10.1080/09654313.2015.1061484

Stadler, A. and Smith, A.M.J. (2017), "Entrepreneurship in vocational education: A case study of the Brazilian context”, Industry and Higher Education, Vol. 31 No. 2, pp. 81-89.

Thanasi-Boçe, M. (2020), "Enhancing students' entrepreneurial capacity through marketing simulation games", Education + Training, Vol. 62 No. 9, pp. 9991013. https://doi.org/10.1108/ET-06-2019-0109

The Royal Society of Edinburgh. (2015), "Publications”, Scotland's National Academy, Available at: https://www.rse.org.uk/publications/

Thompson, P. and Kwong, C. (2016), "Compulsory school-based enterprise education as a gateway to na entrepreneurial career”, International Small Business Journal, Vol. 34 No. 6, pp. 838-869.

Torun, H. and Tumen, S. (2019), "Do vocational high school graduates have better employment out comes than general high school graduates?", International Journalof Manpower, Vol. 40 No. 8, pp. 1364-1388.

Vanevenhoven, J. and Liguori, E. (2013), “The Impact of Entrepreneurship Education: Introducing the Entrepreneurship Education Project”, Journal of Small Business Management, Vol. 51 No. 3, pp. 315-328. DOI: 10.1111/jsbm.12026

Welter F. (2011), “Contextualising Entrepreneurship- Contextual Challenges and the Ways Forward”, Entrepreneurship Theory and Practice, Vol. 35 No. 1, pp. 165-184. doi:10.1111/j.1540-6520.2010.00427.x

Xavier-Oliveira, E., Laplume, A.O. and Pathak, S. (2015), "What motivates entrepreneurial entry under economic inequality? The role of human and financial capital”, Human relations, Vol. 68 No. 7, pp. $1183-1207$.

Yardley, L. (2008). Demonstrating validity in qualitative psychology. In J.A. Smith (Ed.) Qualitative psychology: A practical guide to methods (2nd edn, pp. 235-251). London: Sage

Zacharis, A. (2013), “Entrepreneurship in Brazil: Unlimited Potential”. Forbes, Available at: https://www.forbes.com/sites/babson/2013/04/10/entrepreneurship-in-brazilunlimited-potential/\#67704d506684 